\title{
Leverage and the Cost of Capital: Some Tests Using Nepalese Data
}

\author{
Hari Bahadur Khadka
}

\begin{abstract}
This paper is devoted to test the MM's propositions about the relationship between leverage and cost of capital in the context of Nepalese capital markets. The main objective of the study is to determine whether the firms' overall cost of capital and cost of equity decline with the increasing use of leverage. The results showed a negative but insignificant beta value of the relationship between leverage and the overall cost of capital. Therefore the leverage may not be regarded as contributing variable to the cost of capital function for Nepalese firms. But finding contradicts with the traditional approach of the capital structure theories. It is further concluded that the cost of capital declines not only with leverage because of the tax deductibility feature of interest charge. The relationship between the cost of equity and leverage is also strongly negative. Besides leverage, the size, and D-P Ratio are other important variables that affect the cost of capital in Nepalese context.
\end{abstract}

Key words: cost of capital, capital structure

THE CHOICE OF CAPITAL STRUCTURE, which is simply known as a firm's mix of different securities, is fundamentally a marketing problem. The firm can issue dozens of distinct securities in countless combinations, but it attempts to find the particular combination that maximizes its overall market value (Brealey and Myers 2000). Capital structure of a firm is the permanent financing represented by long-term debt, preferred stock, and shareholders' equity (Weston and Copeland 1992).

Debt and equity are the two major sources through which business organizations, especially corporations, raise funds required to meet their operational needs. A proper balance is necessary between debt and equity to ensure a trade-off between risk and return to the shareholders. A capital structure with reasonable proportions of debt and equity capital, which can maximize the shareholder's wealth to a limit possible and simultaneously can minimize the firm's cost of capital as a whole, is called optimal capital structure. The firms have to pay a fixed charge at every period irrespective to the firm's earnings. Equity provides ownership of the corporation to investors. Being owners, shareholders do have voting right and participate in company's management and control the company affairs. However, shareholders can not claim for dividend for any period until and unless it is decided and declared by the management.

The cost of capital is concerned with what a firm has to pay for the capital - that is, the debt, preferred stock, retained earnings, and common stock - it uses to finance new investments. It can also be thought of as the return required by investors in the firm's securities. It can also be thought of as the minimum rate of return required on new investments undertaken by the firm. As such, the firm's cost of capital is determined in the capital markets and is closely related to the degree of risk associated with new investments, existing assets, and the firm's capital structure. In general, the greater the risk of a firm as perceived by investors, the greater the return investors will require and the greater will be the cost of 
capital.

The cost of capital concept occupies a pivotal place in the theory of financial management as a criterion of allocation capital. This concept has received considerable attention both from theorists and practitioners in recent years. In spite of the voluminous literature on the cost of capital, the question of the effect of capital structure on the cost of capital still remains unresolved (Pandey 1991).

The capital structure management may not be taken seriously in Nepalese companies. Most of the companies have debt capital relatively very higher than equity capital. Consequently, most of them are operating at losses to the extent that payment of interest on loans has been serious issues. Most of the losses are after charging interest on loan (Shrestha 1993). Without the proper combination of capital structure components in financing of the firm, it is impossible to minimize the cost of capital. Determining the cost of capital is a major problem in Nepalese companies. It is in fact an important measuring variable in the financing process of various corporations of Nepal before taking intelligent decision to borrow additional capital for expanding the volume of operation. Management is not able to analyze the cost of capital properly in their firm for investment decision-making (Shrestha 1985).

The capital structure concept has been the subject of controversy since the publication of the two prominent financial researchers, Franco Modigliani and Merton Miller's (MM's) classic paper in 1958. They proved that, under a very restrictive set of assumptions, a firm's overall cost of capital, and therefore its value, is independent of capital structure Modigliani and Miller 1958). However, the traditional belief is that the cost of capital is the function of capital structure. MM (1963) published a follow-up paper in which they relaxed the assumption that there are no corporate taxes. Several years later, Merton Miller (1977) extended the analysis to include personal taxes. In this process, many other researchers put their efforts and they either supported the MM's view or the traditional belief.

Barges (1963), Weston (October, 1965), Davenport (May, 1971), Wippern (1966), Sharma and Rao (1969), Pandey (1991), and others had conducted empirical works in different contexts to test the validity of the MM hypothesis. Most of these researches found that the cost of capital and capital structures are relating and thereby supported the traditional view.

In Nepalese context, it is the subject of curiosity for the researchers, academicians, and other interested parties such as business people to know whether the theories of capital structure and cost of capital are applying to under-developed economy. Therefore, this study attempts to test the empirical relationship between capital structures and the cost of capital in the context of underdeveloped economy such as Nepal by using the data of Nepalese listed companies. Specifically, this study concentrates on examining relationship between the firm's overall cost of capital and its capital structure decisions; cost of equity and leverage, tax advantage of the debt capital. It also tests the theoretical relationship of cost of capital with the size of the firm $(S)$, growth of the firm $(G)$, dividend payout ratio (DPR), and liquidity (Liq.) in Nepalese context.

Section 1 of this paper describes the data and methodology while section 2 presents the models that attempt to explain the relationship between the firm's cost of capital and leverage along with other selected independent variables. In section 3, data analysis is made 
and finally the empirical findings are summarized and the conclusions are given in section 4.

\section{Data and Methodology}

This study is based on secondary data. The financial data have been collected from the financial statements published in the Red Book, volume II and III, published by the Nepal Stock Exchange Limited, Kathmandu, and its web site: http://www.nepalstock..com, covering a period from 1990 to 2005. The sample includes 15 listed-Nepalese firms at Nepal Stock Exchange Ltd. that are using debt capital in their total capitalization. ${ }^{1}$ The study uses simple regression equations to test the relationship between leverage on one hand and one of the dependent variables on the other hand. In multiple regression equations, other independent variables such as firm's size, liquidity, growth, dividend payout ratio, etc., were also included along with leverage.

\section{The Models}

Model I: The theoretical statement of this model is that the cost of capital of firm is influenced by firm's financial leverage, size, growth, dividend payout ratio, and liquidity. The model to be estimated has therefore been specified as under:

$$
K_{o}=a+b_{1} L+b_{2} \ln S+b_{3} G+b_{4} D P R+b_{5} \text { Liq. .. } \quad \ldots \quad \ldots \quad \ldots \quad \text { (1) }
$$

Where Ko, the dependent variable, refers to the firm's overall cost of capital and independent variables are respectively leverage $(\mathrm{L})$, size $(\mathrm{S})$, growth $(\mathrm{G})$, dividend payout ratio (DPR), and liquidity (Liq.). The Model 1 assumes following reasonable a priori hypothesis:

$$
\begin{aligned}
& b_{1}, b_{2}, b_{4}, \text { and } b_{5}<0 \ldots \ldots \\
& \begin{array}{lllll}
b_{3}>0 & \ldots & \ldots & \ldots
\end{array}
\end{aligned}
$$

The expressions (2) and (3) assume that the relationship between $\mathrm{K}_{\mathrm{o}}$ and $\mathrm{L}, \mathrm{S}, \mathrm{DPR}$, and Liq. is positive while the same between $K_{o}$ and $G$ is negative.

Model II: MM argued in their second study that the cost of capital declines with leverage only because of the tax deductibility of interest charges. To test whether their hypothesis gets support from Nepalese data, this model considers the tax adjusted stock yield as the dependent variable in the following equation:

$\left(X^{t}-t R\right) /(V-t D)=a+b_{1} L+b_{2} \ln S+b_{3} G+b_{4} D P R+b_{5} \operatorname{Liq} \ldots \quad \ldots \quad \ldots \quad$ (4)

Where, $\left(X^{t}-t R\right)$ refers to the tax adjusted earnings of the firm that is equal to $X(1-t) ; V$ is the value of the firm; and $\mathrm{tD}$ is tax saving.

Model III: This model helps in testing how cost of equity is related with each of these explanatory variables: leverage, size, growth, dividend payout, and liquidity. The model may be expressed as follows:

$$
K_{e}=a+b_{1} L+b_{2} \ln S+b_{3} G+b_{4} D P R+b_{5} \text { Liq } \ldots
$$

Where, $\mathrm{K}_{\mathrm{e}}$ is the cost of equity funds. Particularly, this model is used to test whether the cost of equity is the linear function of the leverage.

\footnotetext{
${ }^{1}$ Sample includes Nepal Bank Ltd. Nabil Bank Ltd., Nepal Investment Bank Ltd., Standard Chartered Bank Nepal Ltd., Himalayan Bank Ltd., Nepal SBI Bank Ltd., Nepal Battery Company Ltd., Jyoti Spinning Mills Ltd., Nepal Lever Ltd., Soaltee Hotel Ltd., Necon Air Ltd., Bishal Bazaar Company Ltd., Salt Trading Corporation, Nepal Industrial Development Corporation, and Nepal Lube Oil Ltd.
} 


\section{Empirical Analysis}

The pooled regression results estimated in this section are based on data of 15 listed Nepalese listed companies from the year 1990 to 2005. It is also to be noted in the regression equations presented in this section that figures in parentheses indicate t-values. Similarly, the single asterisk sign (*) and double asterisk sing (**) indicate that the result is statistically significant at 1 percent and 5 percent level of significance respectively.

\subsection{Leverage and Cost of Capital}

Traditional approach and MM approach contradict on the relationship of leverage and cost of capital. Traditionalists assume a negative relationship between these variables. However, the cost of capital would increase after a reasonable level of debt. On the other hand, MM concluded no relationship between leverage and cost of capital. In their approach, the capital structure decisions are irrelevant. The simple regression results of the relationship between the firms overall cost of capital $\left(\mathrm{K}_{\mathrm{o}}\right)$ and the leverage $(\mathrm{L})$ is given in Table 1 .

\section{Table 1: Regression Results}

\begin{tabular}{llll}
\hline $\mathrm{K}_{\mathrm{o}}=$ & 0.473 & $-0.390 \mathrm{~L}$ &.$(6)$ \\
& & $(1.208)$ & \\
& $\mathrm{N}=125$ & $\mathrm{R}^{2}$ & $\mathrm{~F}=1.459$ \\
& $=0.012$ & \\
& & \\
\hline
\end{tabular}

The regression results given in Table 1 show that the regression coefficient of leverage has negative sign. The beta coefficient of leverage is statistically insignificant. To a low extent, the relationship noticed here is in line with the traditional approach. The negative beta coefficient implies that the cost of capital declines with increase in leverage.

The regression results of cost of capital $\left(\mathrm{K}_{\mathrm{o}}\right)$ with leverage $(\mathrm{L})$ along with other explanatory variables: firm's size $(\mathrm{S})$, growth $(\mathrm{G})$, dividend payout ratio (DPR), and liquidity (Liq.), are given in Table 2.

\section{Table 2: Regression Results}

\begin{tabular}{|c|c|c|}
\hline \multicolumn{3}{|c|}{$K_{o}=-2.15-0.44 L+0.39 \ln S+0.38 G$} \\
\hline \multicolumn{3}{|c|}{$\begin{array}{c}+0.01 \text { DPR }-0.10 \text { Liq. } \quad \ldots \ldots \ldots \\
(2.08)^{* *} \quad(-0.56)\end{array}$} \\
\hline $\mathrm{N}=120$ & $\mathrm{R}^{2}=0.135$ & $\mathrm{~F}=3.577^{*} *$ \\
\hline
\end{tabular}

The results given in Table 2 show that the beta coefficient of leverage and liquidity are negative and that of size, growth and D-P ratio are positive. The leverage, liquidity and growth do hold the theoretically expected signs whereas the size and D-P ratio do no hold it. Therefore, the hypothesis of the study, expression (2), about the relationship of cost of capital with leverage, and liquidity are accepted. The hypothesis about the relationship between the cost of capital and growth is also accepted (expression 3). The regression coefficient of size and DPR are statistically significant at 1 percent and 5 percent level of significance respectively. So, size and DPR can be regarded as important contributing variables 
for determining the cost of capital in case of Nepalese listed companies. The relationship with leverage, growth and liquidity cannot be confirmed since their beta coefficients are not statistically significant.

The $\mathrm{R}^{2}$ indicates that about 13.5 percent of the variation in cost of capital is explained by the regression model. Despite a lower $\mathrm{R}^{2}$ value, F-value is statistically significant at 5 percent level of significance. Theoretically, it implies that few or at least one independent variables used in the model are important or significant.

The negative beta coefficient of the leverage refers to the negative relationship between the cost of capital and leverage. However, the coefficient is insignificant. Therefore the leverage may not be regarded as an important variable that affects the cost of capital for Nepalese firms. This finding contradicts with the traditional approach of the capital structure theories.

\subsection{Corporate Tax, Cost of Capital and Leverage}

MM agreed that the use of leverage could increase the value of the firm or lower the cost of capital, due to the tax deductibility of the interest charges. The result is also consistent with the traditional view. The purpose of this section is to test the hypothesis that the cost of capital declines with leverage even in the absence of the tax deductibility of interest charges. Therefore, the annual tax-adjusted yield of the corporations is determined and used as dependent variable for this case.

Table 3: Regression Results

\begin{tabular}{ccc}
\hline$(x-t R) /(V-t D)=$ & $0.074-0.117 L-0.017 \ln S$ \\
$(-4.363)^{*}$ & $(-2.283)^{* *}$ \\
$+0.012 \mathrm{G}+$ & $0.001 \mathrm{DPR}-0.034 \mathrm{Liq}$. \\
$(0.400)$ & $(1.600)$ & $(2.690)^{* *}$ \\
$\mathrm{~N}=126$ & $\mathrm{R}^{2}=0.282$ & $\mathrm{~F}=9.499 * *$ \\
\hline
\end{tabular}

The regression results given in Table 3 show a negative beta value for leverage, which is theoretically expected and statistically strong enough to prove the negative relationship. Here the results found similar when the cost of capital, tax-unadjusted, has been replaced by tax-adjusted yield. The objective was to test whether the cost of capital still declines even after eliminating the effect of tax shield on interest charges. It does hold true. Therefore, it is concluded that the cost of capital does not decline only because of the tax deductibility feature of the interest charges in Nepalese context. This finding contradicts with the MM's finding.

\subsection{Cost of Common Equity and Leverage}

$\mathrm{MM}$ argued that there is a linear relationship between the cost of equity and leverage. But the traditional belief in this regard is that the cost of equity either remains constant or increases slightly with moderate level of debt and afterwards increases with leverage at an increasing rate. Both of the views commonly agree on the matter that the cost of equity increases with the increasing use of leverage. The results of simple regression equation of cost of equity run on leverage are given in Table 4. 
Table 4: Regression Results

\begin{tabular}{lll}
\hline$K_{e}=0.065$ & $-0.124 L$ & \\
& $(-1.346)$ & \\
$\mathrm{N}=125$ & $\mathrm{R}^{2}=0.014 \quad \mathrm{~F}=1.812$ \\
\hline
\end{tabular}

The negative beta coefficient implies that the cost of equity declines with increasing use of leverage. However, the beta coefficient of leverage is statistically insignificant. The multiple regression results are presented in Table 5.

\section{Table 5: Regression Results}

\begin{tabular}{ccc}
\hline$K_{e}=-0.304-0.375 L+0.058 \ln S$ \\
$(-5.602)^{*}$ & $(3.154)^{* *}$ \\
$+0.077 G+0.002 D P R$ & $-0.063 \mathrm{Liq}$ \\
$(0.743)$ & $(2.353)^{* *}$ & $(2.056)^{* *}$ \\
$\mathrm{~N}=120$ & $\mathrm{R}^{2}=0.346$ & $\mathrm{~F}=12.185^{*}$ \\
\hline
\end{tabular}

The negative and statistically significant coefficient of leverage indicates that the leverage is negatively correlated with cost of equity. The coefficient indicates that the larger size companies are bearing higher cost of equity. The beta coefficients of growth, DPR, and liquidity are all positive. However, beta of growth is not significant and the betas of DPR and liquidity are significant at 5 percent level of significance. In general, the negative coefficient of the payout variable suggests that investors have preference for current dividend (Pandey 1996). The positive beta value of DPR indicates here that the Nepalese investors have no preference for current dividend in general; rather they prefer future growth of their investment on shares. Similarly, the positive beta of liquidity suggests that the cost of equity of the high-liquidity companies is generally lower than that of low-liquidity companies. It is also theoretically true that when companies maintain higher liquidity, cost increases, and ultimately profitability decreases. In general, there should be positive relationship between cost and liquidity, and negative relationship between cost and profitability. This theoretical contention is supported by the results of this study.

The value of $\mathrm{R}^{2}$ of 0.346 implies that about 34.6 percent of the variation in cost of equity is explained by the independent variables included in the model. The statistically significant F-value indicates that the model is fitting better.

\section{Conclusions}

Based on the analysis and interpretation of the data, this study drew out the following conclusions:

The regression results showed an insignificant negative effect of leverage on firms' cost of capital function. It has proved that the leverage cannot be regarded as a significant variable affecting the firm's cost of capital in Nepalese context. This result, to some extent, supports to the MM's view. Besides leverage, other significant explanatory variables are size, measured by the amount of capital employed, and D-P Ratio. The coefficients of both size and D-P Ratio are positive. The positive beta value of size implies that the larger firms are not able to use their resources effectively compare to small size companies and possibly 
not being able to raise funds at cheaper rate by taking the advantage of their large scale funds collection. The positive beta value of D-P Ratio indicates that the Nepalese investors do not prefer current dividend rather they want growth in their investments on stocks. The growth and liquidity variables are found insignificant in Nepalese context. The cost of capital declines not only with leverage because of the tax deductibility of interest charge. It contradicts with the MM's findings and supports the traditional view. The cost of common equity decreases with increase in the leverage in the case of Nepalese companies.

\section{REFERENCES}

Barges, A. 1963. The Effect of Capital Structure on the Cost of Capital. Englewood Cliffs: N. J. PrenticeHall, Inc.

Brealey, R. A., and Myers, S. C. 2000. Principles of Corporate Finance. $6^{\text {th }}$ ed. New Delhi: Tata McGraw-Hill Publishing Company Ltd.

Modigliani, F. and Miller, M. H. 1963. Corporate Income Taxes and the Cost of Capital: A Correction. American Economic Review: 433-443.

Modigliani, F. and Miller, M. H. 1958. The Cost of Capital, Corporate Finance and the Theory of Investment. American Economic Review : 261-297.

Pandey, I. M. 1991. Capital Structure and the Cost of Capital. New Delhi: Vikas Publishing House Pvt. Ltd.

Rao, C. V. and Lintznberger, R. H. 1970. Leverage and the Cost of Capital in a Less Developed Capital Market: Comment. Journal of Finance : 777-782.

Rao, Hanumanta and Sharma, L. V. 1969. Leverage and the Value of the Firm. Journal of Finance: 673-677.

Sharma, L., and Rao, H. 1969. Leverage and the Value of the Firm. Journal of Finance: 673-677.

Shrestha, Manohar K. 1985. Analysis of Capital Structure in Selected Public Enterprises. Prashasan:The Nepalese Journal of Public Administration 16: 41-49.

Shrestha, Rima D. 1993. Focus on Capital Structure of Selected and Listed Companies. Pravaha Journal of Management 10.

Weston, J. F. and Copeland, T. E. 1992. Managerial Finance. $9^{\text {th }}$ ed. Orlando: The Dryden Press.

Weston, J. Fred. 1965. A Test of Cost of Capital Proposition. Southern Economic Journal 30: 107-112.

Wippern, R. 1966. Financial Structure and Value of the Firm. Journal of Finance : 615-633. 